\section{Time of day as indicator of adolescent alcohol intoxication emergency department presentations}

In line with other countries from wealthier parts of the world, the Netherlands shows clear trends of less alcohol use and less binge drinking by youth since the millennium shift. ${ }^{1}$ Contrary to these trends, the number of underage patients who are admitted to a hospital with alcohol intoxication characteristics is an ongoing and stable health concern in the country. ${ }^{2}$

Knowledge about what time of day patients are brought into the hospital is important for the development of efficient prevention policies. The primary aim of this repeated cross-sectional study was to investigate how time of day variation (morning, afternoon, evening and night) was associated with patient and intoxication characteristics in Dutch adolescents admitted for alcohol intoxication. Furthermore, we also examined how alcohol intoxication hospital admission time trends developed between 2007 and 2017.

In this repeated cross-sectional study, the contents of 5511 patient files were analysed. During the data collection period (2007-2017), paediatric doctors reported cases of alcohol intoxication to the Dutch Paediatric Surveillance Unit, a nationwide surveillance system, with around 95\% participation grade. Time of day for admittance was one question on the questionnaire with four answering options: morning (06:00-11:59), afternoon (12:00-17:59), evening (18:0023:59) and night (00:00-05:59).

Our study shows that adolescent hospital admissions for alcohol intoxication are most frequently seen during the night (64.6\%), followed by evening (28.0\%), afternoon (4.7\%) and morning $(3.0 \%)$. This pattern is rather stable over the months, with a slight increase in the periods of warmer outdoor temperatures (April-August) as well as a peak in February (figure 1).

Over the years (2007-2017), the number of admissions during the morning and afternoon is stable, but there was a strong increase in night-time admissions and a mild increase in evening admissions. The latter two time frames also caused an overall increase in alcohol intoxication treatments in the Netherlands in the decade from our data collection (figure 2).

Our analyses further show that during morning and afternoon admission, the propensity for male patients is higher. Children from parents who disapprove alcohol consumption are most likely to drink at afternoons and evenings, while children who are (partially) allowed to drink have the biggest chance to end up in a hospital during night-time(online supplemental table 1). The group who is admitted during afternoon hours turns out to be the youngest(online supplemental table 2).

Prevention of adolescent alcohol intoxication in the Netherlands should be specifically targeted at adolescents at risk of night-time admissions. Afternoon admissions require special attention as these adolescents were younger and more frequently showed rule-breaking behaviour. Future research will also focus on the possible role of national (holidays, carnival) and local (fairs) events in relationship to alcohol intoxication in minors. Loes de Veld $\odot_{,}^{1,2}$ Anouk Speller, ${ }^{2}$
Joris van Hoof, ${ }^{3}$ Nico van der Lely,

${ }^{1}$ Erasmus School of Health Policy \& Management, Erasmus University Rotterdam, Postbus, The Netherlands

${ }^{2}$ Pediatric Department, Reinier de Graaf Hospital, Delft, The Netherlands

${ }^{3}$ Faculty of Behavioural, Management and Social Sciences, University of Twente, Enschede, The Netherlands

${ }^{4}$ Faculty of Medicine and Health Sciences, University of Antwerp, Antwerp, Belgium

Correspondence to Loes de Veld, Erasmus School of Health Policy \& Management, Erasmus University Rotterdam, Postbus 1738, The Netherlands; develd@eshpm.eur.nl

Funding The authors have not declared a specific grant for this research from any funding agency in the public, commercial or not-for-profit sectors.

Competing interests None declared.

Patient consent for publication Not required.

Provenance and peer review Not commissioned: externally peer reviewed.

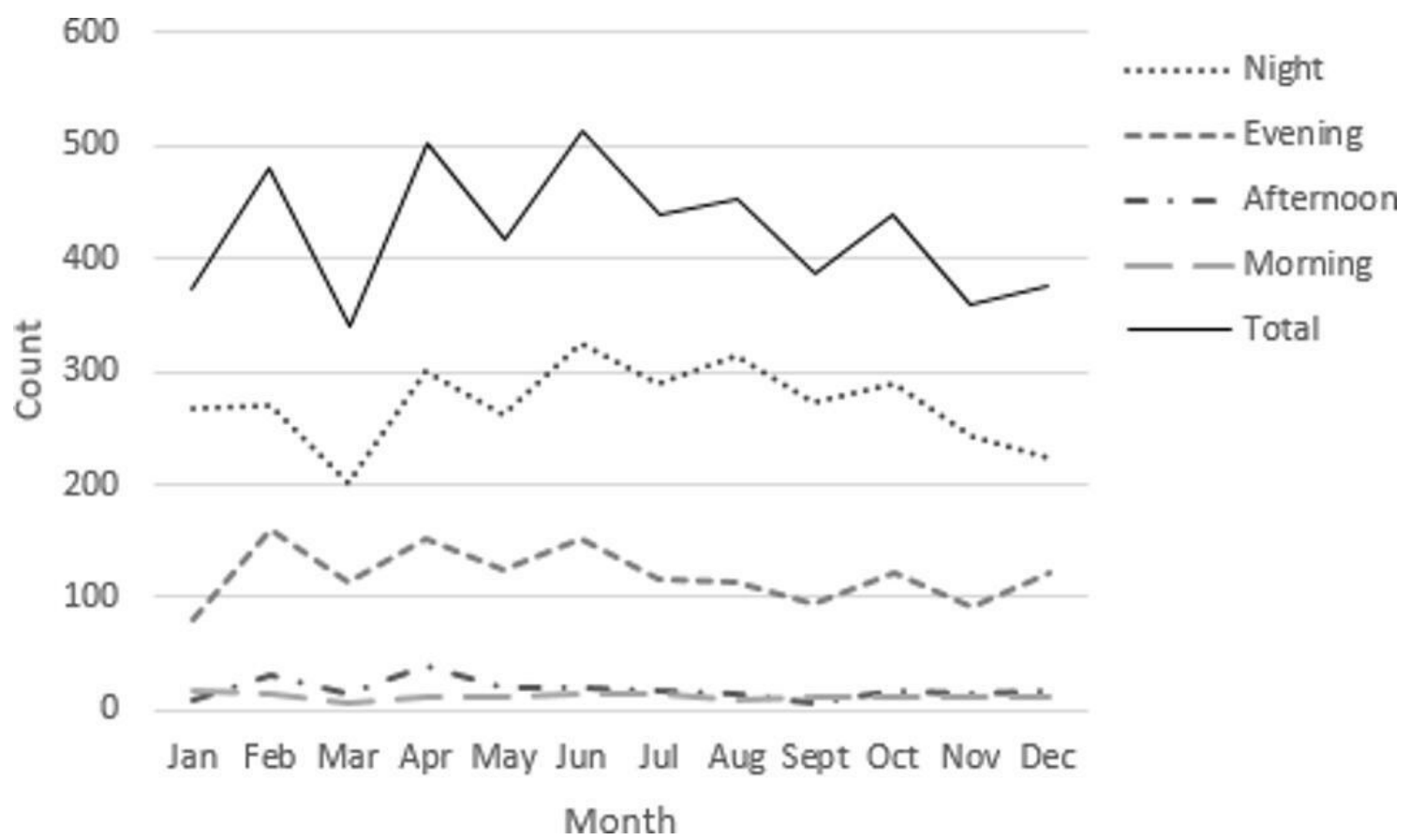

Figure 1 Trends in time of hospital admission. Trends in time of day variation (night, morning, afternoon, evening) in absolute number of hospital emergency department presentations for acute alcohol intoxication, 2007-2017. 


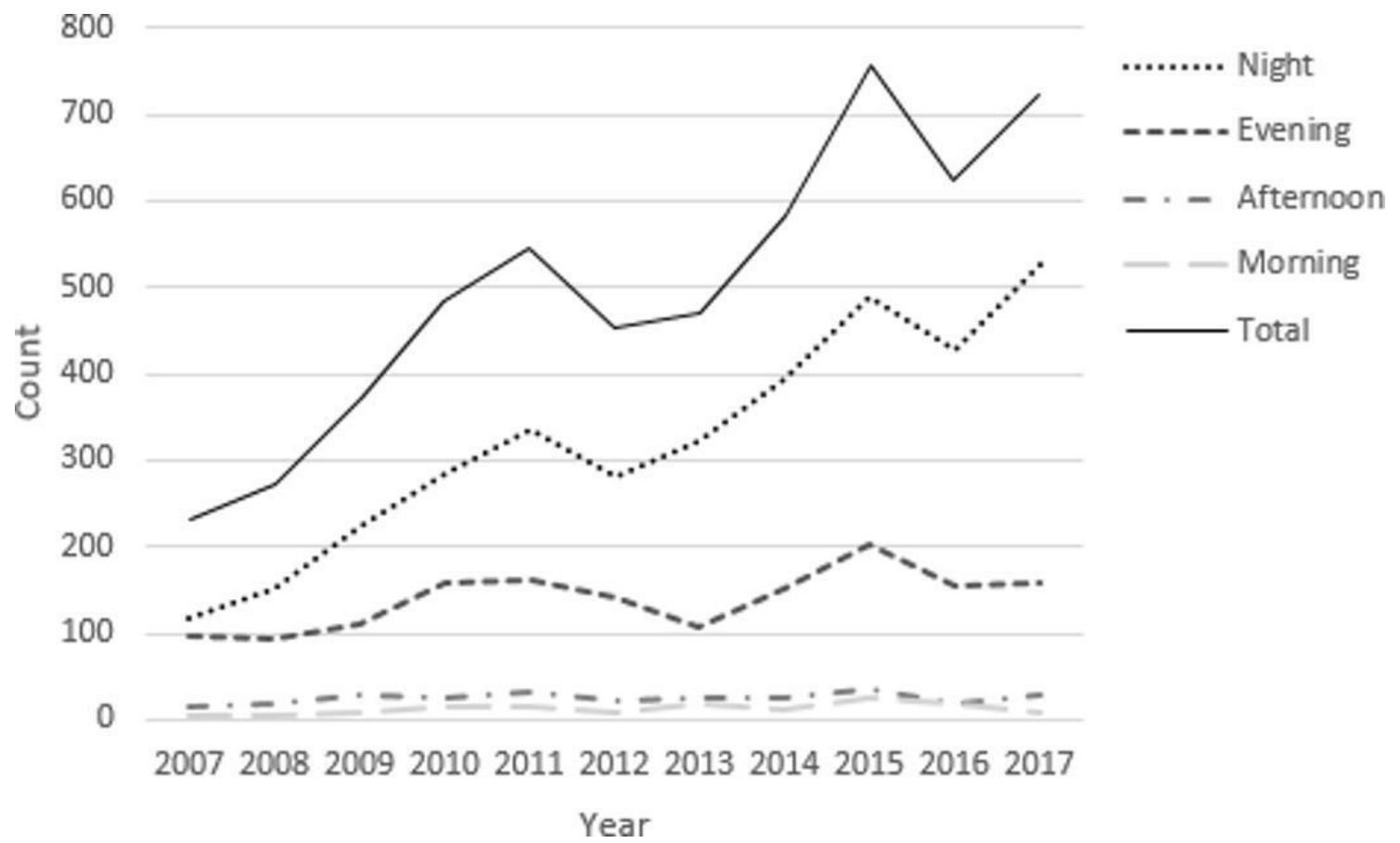

Figure 2 Time of year variation in adolescent acute alcohol intoxication hospital admissions. Trends in time of day variation (night, morning, afternoon, evening) per month during the period 2007-2017.

\section{(2) \\ OPEN ACCESS}

Open access This is an open access article distributed in accordance with the Creative Commons Attribution Non Commercial (CC BY-NC 4.0) license, which permits others to distribute, remix, adapt, build upon this work non-commercially, and license their derivative works on different terms, provided the original work is properly cited, appropriate credit is given, any changes made indicated, and the use is non-commercial. See: http://creativecommons.org/ licenses/by-nc/4.0/.

(c) Author(s) (or their employer(s)) 2021. Re-use permitted under CC BY-NC. No commercial re-use. See rights and permissions. Published by BMJ.

\section{A) Check for updates}

To cite Veld L, Speller A, van Hoof J, et al. Arch Dis Child Epub ahead of print: [please include Day Month Year]. doi:10.1136/ archdischild-2020-321209

Accepted 22 March 2021
Arch Dis Child 2021:0:1-2. doi:10.1136/archdischild-2020-321209

\section{ORCID iD}

Loes de Veld http://orcid.org/0000-0001-5218-7274

\section{REFERENCES}

1 Pape H, Rossow I, Brunborg GS. Adolescents drink less: how, who and why? A review of the recent research literature. Drug Alcohol Rev 2018;37(Suppl 1):S98-114.

2 de Veld L, van Hoof JJ, Ouwehand S, et al. Age at first alcohol use as a possible risk factor for adolescent acute alcohol intoxication hospital admission in the Netherlands. Alcohol Clin Exp Res 2020;44:219-24. 